\title{
Performance, nutrient retention efficiency, total ammonia and reactive phosphorus excretion of growing European sea-bass ( Dicentrarchus labrax, L.) as affected by diet processing and feeding level
}

\author{
R. Ballestrazzi *, D. Lanari, E. D’Agaro \\ Dipartimento di Scienze della Produzione Animale, Università degli Studi di Udine, Via San Mauro 2, \\ 33010 Pagnacco, UD, Italy
}

\begin{abstract}
One hundred and sixty European sea-bass $(78.5 \pm 8.9 \mathrm{~g})$ were randomly assigned to 8 fibreglass tanks $\left(\begin{array}{lll}160 & 1\end{array}\right)$ according to a $2 \times 2$ experimental design [2 processing techniques: extruded diet (E) vs pelleted diet (P); 2 feeding levels: 0.86 (1) vs 1.06\% b.w. (2)], with 2 replicates for each treatment. After 195 days, E2 fed fish reached the highest live weight (329 vs $281 \mathrm{~g}$ ), daily weight gain (1.29 vs $1.04 \mathrm{~g}$ ) and specific growth rate (SGR: 0.74 vs 0.65). No difference was noted among diets in feed efficiency (FE) and protein efficiency ratio (PER), although a trend to better FE (0.73 vs 0.65$)$ and PER (1.48 vs 1.28) was noted for E1 fed fish. Hepatosomatic index was significantly higher in E2 and E1 fed fish (2.56 and $2.53 \%$ b.w., respectively), while the lowest mesenteric fat index occurred in $\mathrm{P} 1$ fed fish (4.37 vs $>5 \%$ b.w.). P1 and E1 fed fish showed the highest protein retention $(\approx 25 \%)$, but the highest energy retention was observed with extruded diets fed at $0.86 \%$ b.w. (40.2\%). Total $\mathrm{NH}_{3}$ (395 and $387 \mathrm{mg} \mathrm{kg}^{-1}$ b.w. day ${ }^{-1}$ ) and reactive phosphorus excretion (136 and $110 \mathrm{mg} \mathrm{kg}^{-1}$ b.w. day ${ }^{-1}$ ) were not affected by the processing method of the diet. (C) 1998 Elsevier Science B.V.
\end{abstract}

Keywords: Dicentrarchus labrax; Diet processing-feeding level; Ammonia and reactive phosphorus excretion

\footnotetext{
* Corresponding author. Tel.: +39-432-650110; Fax: +39-432-660614. E-mail: rodolfo.ballestrazzi@dspa.uniud.it
} 


\section{Introduction}

During the last decade, there has been a marked increase in the use of extruded diets for feeding fish. These diets have superior water stability, better floating properties and a higher energy content than pelleted diets (Hilton et al., 1981; Cho et al., 1991; Johnsen and Wandsvik, 1991). The main effects on fish are: an increase in fish growth, an improvement in feed conversion (Robert et al., 1993; Silver et al., 1993; Lanari et al., 1995), a delay in gastric emptying time, an increase in HSI and liver glycogen content, with no effect on carcass composition (Hilton et al., 1981). A significant decrease in nitrogen and phosphorus discharge in waste waters by fish farms has also been observed (Alsted, 1991; Kiaerskou, 1991; Cho, 1993; Johnsen et al., 1993).

The majority of the studies, where extrusion was compared to pelleting, have been performed on single extruded ingredients instead of considering the whole diet, to demonstrate an improvement in carbohydrate digestibility (Luquet and Bergot, 1976; Pieper and Pfeffer, 1980; Kaushik et al., 1989; Takeuchi et al., 1990; Pfeffer et al., 1991; Arnesen and Krogdahl, 1993). In the past, some authors have studied the effects of the processing method (pelleting vs extrusion) of the same basal mix on physical properties of the product, nutrient losses and fish performance (Slinger et al., 1979; Hilton et al., 1981), but nowadays different extruders with different processing conditions are available. Besides, some of the positive response of fish to extruded diets seems to depend not on the processing method 'per se' but on the higher fat content of the extruded diets.

From a practical point of view, the improvement in nutrient retention and performance observed with extruded diets (Johnsen et al., 1993; Robert et al., 1993; Lanari et al., 1995) has not resulted in an adjustment in the old feeding charts for fish, according to Cho (1992), and feed efficiency has improved little, mainly due to fish overfeeding. The use of extruded diets has grown enormously in the past few years in marine farms and intensive 'valli' of the Mediterranean sea, but little data are available for sea bass and other marine species (sea bream, dentex, Sciaenidae, etc.). There is a need to have a better understanding of the optimal feeding levels of extruded diets for these species, due to their different feeding behaviour and voluntary feed intake compared to salmonids, and to the wide annual range of the temperatures in these farming areas.

The aims of this study were to determine: (1) the physiological response of European sea bass (rate of gain, feed efficiency and body composition) fed the same diet, processed either by extrusion or steam pelleting, at different feeding levels; and (2) the effects of these processing methods on $\mathrm{NH}_{3}$ and reactive phosphate excretion in European sea bass.

\section{Materials and methods}

\subsection{Growth trial}

One hundred and sixty European sea bass (Dicentrarchus labrax, L., $78.5 \pm 8.9 \mathrm{~g}$ ) were randomly allotted to 8 fibreglass tanks (160 1) according to a $2 \times 2$ experimental design [2 processing techniques: extruded diet (E) vs steam pelleted diet (P); 2 feeding rates: 0.86 (1) vs $1.06 \%$ b.w. (2)]. Consequently, four experimental treatments arose: E1, 
E2, P1 and P2; with 2 replicates per treatment. Each tank was supplied by a constant flow of brackishwater (temperature $=23.1 \pm 2.1^{\circ} \mathrm{C}$; dissolved oxygen $=8.5 \pm 2.5 \mathrm{mg}$ $1^{-1}$; salinity $=21.2 \pm 3.6 \%$ NaCl).

The growth trial lasted 195 days and was performed at the valle da pesca 'Villa Bruna', in the Marano lagoon. Portions of the same practical sea bass diet were processed through a pellet mill (Tenchini: mod. FT180) and through a monoscrew extruder (Wenger: mod. X185) (Table 1).

Feed was distributed 5-7 times a day, by automatic dispensers, at the feeding rate previously reported (Table 2). Diets were periodically sampled and analyzed according to AOAC methods (1995), whereas crude fat was determined after acid hydrolysis (Sanderson, 1986). Gross energy content was determined by adiabatic bomb calorimetry (IKA 400), and phosphorus by a photometric method (AOAC, 1995; Ref. 4.8.14).

Mortality and water variables were checked daily and fish were weighed fortnightly. Eighteen fish were sacrificed at the beginning of the experiment and 7 fish per tank at

Table 1

Ingredient content $\left(\mathrm{g} \mathrm{kg}^{-1}\right)$, proximate analysis $(\%)$ and gross energy content of the experimental diet

\begin{tabular}{|c|c|c|c|}
\hline & Steam pelleted diet ${ }^{a}$ & & Extruded diet $^{b}$ \\
\hline Fish meal (Chile) & & 260 & \\
\hline Herring meal (999) & & 155 & \\
\hline Meat meal & & 100 & \\
\hline Blood meal spry (dehydrated) & & 50 & \\
\hline Dried fish solubles & & 40 & \\
\hline Soybean defatted meal & & 80 & \\
\hline Torula yeast (dehydrated) & & 25 & \\
\hline Corn starch & & 75 & \\
\hline Wheat flour & & 70 & \\
\hline Fish oil & & 119 & \\
\hline Soybean lecithin & & 10 & \\
\hline Vitamin mineral mix ${ }^{c}$ & & 16 & \\
\hline \multicolumn{4}{|l|}{ Proximate analyses } \\
\hline Moisture (\%) & 9.33 & & 5.80 \\
\hline Crude protein $(\%)$ & 48.85 & & 48.48 \\
\hline Ether extract $(\%)$ & 16.68 & & 17.91 \\
\hline $\operatorname{Ash}(\%)$ & 11.31 & & 10.94 \\
\hline Crude fiber $(\%)$ & 2.03 & & 2.96 \\
\hline $\mathrm{P}(\%)$ & 2.06 & & 2.09 \\
\hline Energy $\left(\mathrm{kJ} \mathrm{g}^{-1}\right)$ & 20.56 & & 21.48 \\
\hline
\end{tabular}

\footnotetext{
${ }^{\mathrm{a}}$ Tenchini FT180 pellet mill: HP 5.5; Die working width, $4 \mathrm{~cm}$; Total thickness die, $4 \mathrm{~cm}$; Inlet die $\emptyset, 6.0 \mathrm{~mm}$; Pellet $\varnothing, 5.0 \mathrm{~mm}$; Temperature, $80^{\circ} \mathrm{C}$; Feed rate, $100 \mathrm{~kg} \mathrm{~h}^{-1}$; Drying condition: room temperature.

${ }^{\mathrm{b}}$ Wenger extruder (mod: X185): Die temperature, $100-120^{\circ} \mathrm{C}$; Total water rate, $16 \%$; Steam rate, $2 \%$; Pressure, 300 psi; Feed rate, $200 \mathrm{~kg} \mathrm{~h}^{-1}$; L/D ratio, 8; Screw speed, 300 rpm; Residence time, 25 s; Drying conditions, $100^{\circ} \mathrm{C} \times 25 \mathrm{~min}$.

${ }^{\mathrm{c}}$ Vitamin-mineral supplement (except where units are given, values are in $\mathrm{mg} \mathrm{kg}^{-1}$ diet): vit. A, 21,000 IU; vit $\mathrm{D}_{3}, 2700 \mathrm{IU}$; vit. E, 225; vit. K, 12.6; thiamin $\mathrm{HCl}, 14$; riboflavin, 20; nicotinic acid 120; biotin, 10 ; vit. $\mathrm{B}_{12}, 0.01$; L-ascorbyl-2 polyphosphate, 100; choline chloride, 1120; inositol, 180; $\mathrm{MnSO}_{4}, 40 ; \mathrm{FeSO}_{4}, 50$; $\mathrm{ZnSO}_{4}, 70 ; \mathrm{CuSO}_{4}, 6$; BHT 150 .
} 
Table 2

Growth and feed efficiency of European sea bass fed pelleted or extruded diets at two different feeding levels

\begin{tabular}{|c|c|c|c|c|c|}
\hline & P1 & E1 & $\mathrm{P} 2$ & E2 & Pooled SEM ( $4 d f)$ \\
\hline Tank ration $^{1}$ (\% b.w.) & $0.86^{\mathrm{B}}$ & $0.86^{\mathrm{B}}$ & $1.08^{\mathrm{A}}$ & $1.04^{\mathrm{A}}$ & 0.0424 \\
\hline Initial live weight $^{2}(\mathrm{~g})$ & 79.0 & 79.1 & 77.8 & 78.2 & 2.0316 \\
\hline Final live weight $(\mathrm{g})$ & $254.9^{\mathrm{B}}$ & $291.9^{\mathrm{A}, \mathrm{B}}$ & $296.4^{\mathrm{A}}$ & $329.4^{\mathrm{A}}$ & 8.6835 \\
\hline $\mathrm{SGR}^{3}$ & $0.60^{\mathrm{C}}$ & $0.67^{\mathrm{B}}$ & $0.69^{\mathrm{B}}$ & $0.74^{\mathrm{A}}$ & 0.0101 \\
\hline Daily weight gain $\left(\mathrm{g} \mathrm{fish}^{-1}\right)$ & $0.90^{\mathrm{C}}$ & $1.09^{\mathrm{B}}$ & $1.12^{\mathrm{B}}$ & $1.29^{\mathrm{A}}$ & 0.0361 \\
\hline Daily protein gain $\left(\mathrm{mg}\right.$ fish $\left.^{-1}\right)$ & $163.4^{\mathrm{C}}$ & $195.2^{\mathrm{B}}$ & $206.2^{\mathrm{B}}$ & $225.5^{\mathrm{A}}$ & 5.7446 \\
\hline Daily energy gain $\left(\mathrm{kJ} \mathrm{fish}^{-1}\right)$ & $7.98^{\mathrm{C}}$ & $10.11^{\mathrm{B}, \mathrm{C}}$ & $10.75^{\mathrm{A}, \mathrm{B}}$ & $12.58^{\mathrm{A}}$ & 0.4914 \\
\hline Feed efficiency ${ }^{4}$ & 0.71 & 0.73 & 0.61 & 0.63 & 0.0417 \\
\hline $\mathrm{PER}^{5}$ & 1.38 & 1.48 & 1.18 & 1.28 & 0.0807 \\
\hline
\end{tabular}

Means within the same row not sharing a common superscript letter are significantly different: ${ }^{\mathrm{A}, \mathrm{B}, \mathrm{C}}$ : $P<0.01$.

${ }^{1}$ Ration was calculated as: $\mathrm{g} / 100 \mathrm{~g}$ tank fish weight.

${ }^{2} \mathrm{ABW}=$ average tank weight.

${ }^{3}$ Specific growth rate calculated as: $\mathrm{SGR}=(\ln$ final weight $-\ln$ initial weight $) \times 100 /$ days

${ }^{4}$ Feed efficiency ratio calculated as: $\mathrm{FE}=$ (fish weight gain, $\left.\mathrm{g}\right) /($ feed intake, $\mathrm{g}$ dry matter).

${ }^{5}$ Protein efficiency ratio calculated as: $\mathrm{PER}=$ (fish weight gain, $\left.\mathrm{g}\right) /($ protein intake, $\mathrm{g}$ ).

the end. The gastrointestinal contents were removed and then each fish was minced and freeze-dried. The chemical composition and the energy content of individual fish were determined with the same methods used for feeds.

All data were submitted to two-way analysis of variance. LSD test was used for comparison between means (Snedecor and Cochran, 1982).

\subsection{Excretion trial}

Six groups of five fish were pre-adapted for 4 weeks to the experimental diets and to six fibreglass tanks supplied with a constant flow $\left(11 \mathrm{~min}^{-1}\right)$ of brackish water (see growth trial). Fish were fed $1.06 \%$ b.w., in a single meal (at 8:00 AM) according to a $2 \times 2$ latin square design ( 2 diets: E vs P, 2 periods), and 3 replicates, with 6 days adaptation phase to the feeding level, followed by a 24 -h water sampling period. Every $90 \mathrm{~min}$, water was sampled through a central drain pipe, without disturbing the fish. Temperature (portable thermometer HI 8053), salinity (Atago SC28 salinometer), dissolved oxygen (YSI oxymeter mod. 57) and $\mathrm{pH}$ (Orion 250A) were immediately determined. Samples were then acidified $\left(\mathrm{H}_{2} \mathrm{SO}_{4} 2 \mathrm{~N}\right)$ and frozen. Total ammonia and reactive phosphorus were measured within $24 \mathrm{~h}$ according to Strickland and Parson (1972), after thawing and neutralizing the $\mathrm{pH}$. The amount of metabolites excreted were calculated according to Kaushik (1980). Data were subjected to statistical analysis according to the $2 \times 2$ latin square design (Snedecor and Cochran, 1982).

\section{Results}

The moisture content of the extruded diet was lower than the pelleted diet, while the crude fat, crude fiber and gross energy were slightly higher (Table 1). 
Table 3

Slaughter variables and whole body composition (\% DM) of European sea bass fed pelleted or extruded diet at two different feeding level

\begin{tabular}{|c|c|c|c|c|c|c|}
\hline & \multirow[t]{2}{*}{ Initial } & \multicolumn{4}{|l|}{ Final } & \multirow[t]{2}{*}{ Pooled SEM $(d f=52)$} \\
\hline & & P1 & E1 & $\mathrm{P} 2$ & E2 & \\
\hline$\overline{\mathrm{K}^{1}}$ & - & $1.72^{\mathrm{b}}$ & $1.82^{\mathrm{a}, \mathrm{b}}$ & $1.87^{\mathrm{a}}$ & $1.79^{\mathrm{a}, \mathrm{b}}$ & 0.1342 \\
\hline $\mathrm{DP}^{2}(\%)$ & 88.1 & $92.1^{\mathrm{a}}$ & $91.1^{\mathrm{a}, \mathrm{b}}$ & $90.9^{\mathrm{b}}$ & $90.7^{\mathrm{b}}$ & 1.4369 \\
\hline $\mathrm{MF}^{3}(\%)$ & 4.73 & $4.37^{\mathrm{a}}$ & $5.10^{\mathrm{a}, \mathrm{b}}$ & $5.66^{\mathrm{b}}$ & $5.64^{\mathrm{b}}$ & 1.2043 \\
\hline $\mathrm{HSI}^{4}(\%)$ & 2.58 & $2.15^{\mathrm{a}}$ & $2.50^{\mathrm{b}, \mathrm{c}}$ & $2.26^{\mathrm{a}, \mathrm{b}}$ & $2.56^{\mathrm{c}}$ & 0.3667 \\
\hline \multicolumn{7}{|l|}{ Body composition } \\
\hline Moisture (\%) & 65.7 & $64.8^{\mathrm{b}}$ & $63.5^{\mathrm{a}, \mathrm{b}}$ & $62.7^{\mathrm{a}}$ & $62.7^{\mathrm{a}}$ & 1.8375 \\
\hline Crude protein (\% DM) & 53.2 & $51.9^{\mathrm{A}}$ & $49.1^{\mathrm{A}, \mathrm{B}}$ & $49.4^{\mathrm{A}, \mathrm{B}}$ & $46.9^{\mathrm{B}}$ & 3.0071 \\
\hline Crude fat (\% DM) & 32.9 & $34.1^{\mathrm{b}}$ & $37.1^{\mathrm{a}, \mathrm{b}}$ & $37.6^{\mathrm{a}}$ & $39.1^{\mathrm{a}}$ & 3.9480 \\
\hline Ash (\% DM) & 12.5 & 12.2 & 11.4 & 11.5 & 11.7 & 1.2726 \\
\hline $\mathrm{P}(\% \mathrm{DM})$ & 2.05 & $1.95^{\mathrm{a}}$ & $1.82^{\mathrm{a}, \mathrm{b}}$ & $1.96^{\mathrm{a}}$ & $1.78^{\mathrm{b}}$ & 0.1980 \\
\hline Energy $\left(\mathrm{kJ} \mathrm{g}^{-1} \mathrm{DM}\right)$ & 25.19 & $24.25^{\mathrm{B}}$ & $25.41^{\mathrm{A}, \mathrm{B}}$ & $25.75^{\mathrm{A}}$ & $26.14^{\mathrm{A}}$ & 1.1623 \\
\hline
\end{tabular}

Means within the same row not sharing a common superscript letter are significantly different: ${ }^{\mathrm{a}, \mathrm{b}, \mathrm{c}}: P<0.05$; $\mathrm{A}, \mathrm{B}, \mathrm{C}: P<0.01$.

${ }^{1}$ Condition factor calculated as: $\mathrm{K}=$ Fish weight $(\mathrm{g}) \times 100 /$ standard length $^{3}(\mathrm{~cm})$.

${ }^{2}$ Dressing percentage calculated as: $\mathrm{DP}=($ Fish weight - viscera weight, $\mathrm{g}) \times 100 /($ empty fish weight, $\mathrm{g})$.

${ }^{3}$ Mesenteric fat calculated as: $\mathrm{MF}=($ mesenteric fat weight, $\mathrm{g}) \times 100 /($ empty fish weight, $\mathrm{g})$.

${ }^{4}$ Hepatosomatic index calculated as: HSI $=($ liver weight, $\mathrm{g}) \times 100 /($ empty fish weight, $\mathrm{g})$.

The final weight of fish fed the P1 diet was significantly lower than that of P2 and E2 fed fish. Specific growth rate (SGR) and daily weight gains of fish fed E1 and P2 diets were higher than those observed in fish fed pelleted diets at low feeding level and lower than those obtained for the E2 groups (Table 2). The highest daily protein gain (225.5 $\mathrm{mg}$ day $\left.^{-1}\right)$ and daily energy gain $\left(12.58 \mathrm{~kJ} \mathrm{fish}^{-1}\right)$ occurred in fish fed the extruded diet at the medium level, while the lowest values were for the P1 fed fish $\left(163.4 \mathrm{mg} \mathrm{day}^{-1}\right.$ and $7.98 \mathrm{~kJ} \mathrm{fish}^{-1}$, respectively, $P<0.01$ ). Feed efficiency and PER values did not

Table 4

Nutrient retention efficiency (\% gross intake); ammonia excretion and reactive phosphorus released by European sea bass fed pelleted or extruded diet

\begin{tabular}{|c|c|c|c|c|c|}
\hline & $\mathrm{P} 1$ & E1 & $\mathrm{P} 2$ & E2 & Pooled SEM (4 gl) \\
\hline $\mathrm{GER}^{1}$ & $33.6^{\mathrm{b}}$ & $40.2^{\mathrm{a}}$ & $31.4^{\mathrm{b}}$ & $35.9^{\mathrm{a}, \mathrm{b}}$ & 1.69 \\
\hline $\mathrm{GPR}^{2}$ & 24.7 & 24.7 & 21.6 & 21.4 & 1.22 \\
\hline $\mathrm{P}^{3}$ & 20.1 & 19.6 & 19.1 & 17.7 & 0.48 \\
\hline Total $\mathrm{NH}_{3}$ excretion $\left(\mathrm{mg} \mathrm{kg}^{-1}\right.$ b.w. $\left.\mathrm{d}^{-1}\right)$ & - & - & 395.3 & 386.7 & 23.29 \\
\hline Reactive phosphorus ${ }^{4}\left(\mathrm{mg} \mathrm{kg}^{-1}\right.$ b.w. $\left.\mathrm{d}^{-1}\right)$ & - & - & 136.4 & 109.7 & 29.45 \\
\hline
\end{tabular}

Means within the same row not sharing a common superscript letter are significantly different: ${ }^{\mathrm{a}, \mathrm{b}}: P<0.05$.

${ }^{1}$ Gross energy retention $=($ fish energy gain, $\mathrm{kJ}) /($ energy intake, $\mathrm{kJ}) \times 100$.

${ }^{2}$ Gross protein retention $=($ fish protein gain, $\mathrm{g}) /($ protein intake, $\mathrm{g}) \times 100$.

${ }^{3}$ Gross phosphorus retention $=($ fish $\mathrm{P}$ gain, $\mathrm{g}) /(\mathrm{P}$ intake, $\mathrm{g}) \times 100$.

${ }^{4}$ Faecal phosphorus leached in the water. 


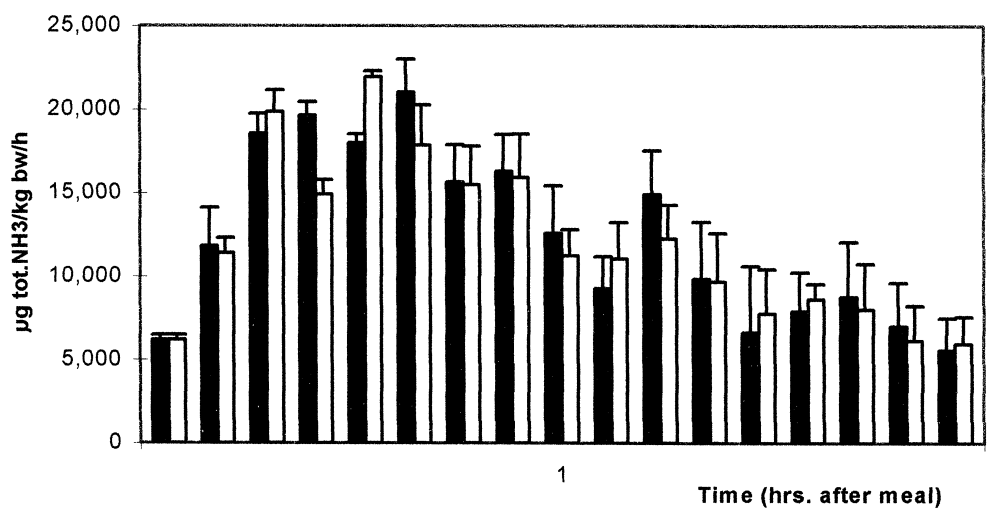

Fig. 1. Total $\mathrm{NH}_{3}$ excretion of European sea bass fed pelleted (black color) or extruded diet (white color).

differ among treatments, although a trend was shown towards better values at low feeding level and with the extruded diet (Table 2).

Dressing percentage and mesenteric fat indices were higher and lower, respectively, in sea bass fed the pelleted diet at the low feeding level, in comparison with fish fed the pelleted or extruded diet at medium feeding level (Table 3). Fish receiving the extruded diet at low feed intake gave intermediate results. HSI values increased with the extruded diet and according to increasing feeding level.

Final body composition of sea bass changed markedly in comparison with initial composition. Moisture and protein content were higher in fish fed the P1 diet and significantly decreased when feed intake was increased either with pelleted or extruded diet. Fish fed the E1 diet had intermediate results. Fat and energy content of fish showed trends opposite to those observed for moisture and protein levels. Body ash level was not affected by dietary treatments. P content was higher in fish fed the pelleted diets (Table 3).

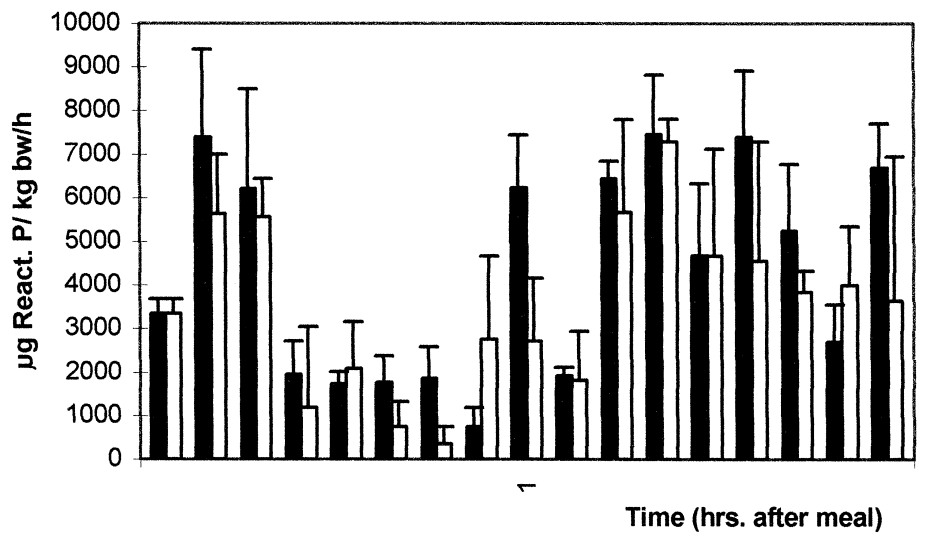

Fig. 2. Reactive phosphorus production by European sea bass fed pelleted (black color) or extruded diet (white color). 
Fish fed the E1 diet had the highest energy retention $(40.2 \%)$, while P2 the lowest (31.4\%; $P<0.05)$. Due to the low number of replicates for the experimental treatments, the decreasing trend of the protein retention according to increasing feeding level was not statistically confirmed. Gross phosphorus retention was close to $20 \%$, irrespective of the diet type of processing or feeding level (Table 4).

The daily $\mathrm{NH}_{3}$ excretion of sea bass $\left(385-395 \mathrm{mg}\right.$ total $\mathrm{NH}_{3} \mathrm{~kg}^{-1}$ b.w. day ${ }^{-1}$ ) was unaffected by the type of diet processing (Table 4). The total ammonia excretion by fish in a 24-h period is reported in Fig. 1. Peak values occurred $6 \mathrm{~h}$ after feed distribution for the extruded diet and after $7.5 \mathrm{~h}$ for the pelleted diets. The daily amount of reactive phosphorus leached in the water was slightly lower for the extruded diets than the pelleted diets (109.7 vs. $136.4 \mathrm{mg} \mathrm{P} \mathrm{kg}^{-1}$ b.w. day ${ }^{-1} ; P<0.07$; Table 4). The concentration of soluble $\mathrm{P}$ in the tanks increased $1.5-3 \mathrm{~h}$ after feeding, returned to basal levels thereafter, showing a common trend to increase again after $15 \mathrm{~h}$, both for $\mathrm{E}$ and $\mathrm{P}$ diet fed groups (Fig. 2).

\section{Discussion}

In this trial, both the extruded diet and the increased feeding level significantly affected final weight, SGR, and daily weight gain. Similar effects of feeding level have previously been observed in rainbow trout fed at low $(0.9 \%$ b.w.) or moderate $(1.1 \%$ b.w.) feeding levels by Lanari et al. (1995), whereas Hilton et al. (1981) noted that rainbow trout fry reared on an extruded diet had lower weight gains but higher feed efficiency than those reared on a pelleted diet. Nevertheless, it is worth noting that fish size may have an effect on these observations.

The growth rate and feed efficiency that we observed were higher than those previously reported for sea bass with similar levels of pelleted diets (Metailler et al., 1980, 1981; Hidalgo and Alliot, 1988; Ballestrazzi et al., 1994; Ballestrazzi and Lanari, 1996). Also the protein efficiency ratio (1.28-1.48) was better than PER values reported for fry or ongrowing sea bass by the previously cited researchers.

Enlarged livers and increased liver glycogen were observed in rainbow trout fed extruded diets by Hilton et al. (1981), while Mosconi-Bac (1990) reported a hepatic disturbance (large deposits of lipid droplets) in sea bass fry fed to satiation on crumbled diets. Also in this study, enlarged livers occurred, nevertheless the high weight gains observed during the experiment (6.5 months), confirmed that the sea bass readily adapted to the extruded diets, if nutritionally balanced and distributed at $1 \%$ b.w. daily.

The lack of effect of the extruded diet on rainbow trout body composition reported by Hilton et al. (1981) can be explained by the small final size of fish, too low ( $\sim 40 \mathrm{~g})$ to be clearly affected by the diets. An increase in feeding level, irrespective of the diet type, causes a marked decrease of moisture and protein body content and a corresponding increase of fat level in fish (Reinitz, 1983; Storebakken and Austreng, 1987) and this also happened in this trial. Nevertheless, higher fat levels in sea bass body does not necessarily mean fatter fillets since the liver and mesentery are fat storage sites in this species. 
There are two components of total $\mathrm{NH}_{3}$ excretion in fish: the endogenous (for maintenance) and exogenous fractions (Iwata, 1970; Brett and Groves, 1979). While the first fraction is affected by fish size and water temperature (Ogino et al., 1973; Savitz, 1969), the second is mainly influenced by nitrogen intake, i.e., dietary protein quality and quantity (Brett and Zala, 1975; Kaushik, 1980; Kaushik and Cowey, 1991). Several researchers have reported on both $\mathrm{NH}_{3}$ production of starved sea bass and their post-prandial $\mathrm{NH}_{3}$ excretion (Guérin-Ancey, 1976; Spiridakis, 1989; Vitale-Lelong, 1989; Ballestrazzi et al., 1994). A general trend of a decrease in the first fraction, due to sea bass size (from $450 \mathrm{mg} \mathrm{N}$ total $\mathrm{kg}^{-1}$ day ${ }^{-1}$ : 2-6 g fry to $160 \mathrm{mg} \mathrm{N}-\mathrm{NH}_{4} \mathrm{~kg}^{-1}$ day $^{-1}: 120 \mathrm{~g}$ fish) can be deducted from their data. The post-prandial patterns of ammonia excretion are more complex due to the different conditions these authors adopted (different plants, different water flow rate, different temperature), with different fish size, stocking density and different nitrogen intakes. Sea bass fed diets containing plant protein sources or high protein levels showed higher post-prandial $\mathrm{NH}_{3}$ excretion than those fed diets containing animal proteins or low protein levels (Ballestrazzi et al., 1994). In this trial the total $\mathrm{NH}_{3}$ excretion, unaffected by the type of diet processing, was higher than post-prandial excretion in the experiment previously cited, although nitrogen intakes were very similar (600 vs 630-790 mg $\mathrm{N} \mathrm{kg}^{-1}$ b.w.), and was probably due to the different ingredient composition of the diets.

The soluble forms of phosphorus affect water quality directly, whereas the particulate form settles to the bottom of the tank or accumulates in the sediment (Lall, 1991). In this trial the leached phosphorus produced by sea bass fed either the extruded or pelleted diet was similar to the values previously obtained by feeding sea bass only with animal protein sources (Ballestrazzi et al., 1994). An estimation of the phosphorus balance in $\mathrm{P} 2$ and E2 fed fish, considering dietary $\mathrm{P}$ content $(\sim 2.0 \%$ both $)$, the phosphorus retention (19.1 vs. $17.9 \%$ ) and the soluble phosphorus (136.4 vs. $109.7 \mathrm{mg} \mathrm{kg}^{-1}$ b.w. day ${ }^{-1}$ ), indicates that the settling fraction would be higher with the extruded diets than with the pelleted form. This would have environmental positive effects since this fraction is only partly or slowly released from the sludge in soluble forms (Enell, 1987; Persson, 1988).

The extruded diet, increasing the energy retention efficiency, with no effect on protein retention, would be less convenient, at least at the operating temperature adopted $\left(23.1^{\circ} \mathrm{C}\right)$, when no problems for the feed intake of this species are encountered. Considering fish growth, their body composition and gross nutrient retention efficiencies, the best results, in this study, were certainly given by feeding the extruded diet at low feeding level (E1), because the rate of growth was adequate $\left(>1 \mathrm{~g} \mathrm{day}^{-1}\right)$, body composition was similar to that of the P2 fed group, but the amount of diet distributed to fish was $17.9 \%$ less. Fish feeding the extruded diet at higher feeding level (E2) grew more but showed negative effects on their fat and protein body contents.

\section{Acknowledgements}

This work was performed as part of the Italian CNR-RAISA Project 'Interaction between farm technology and the organization of animal production'. Publication No. 
2953. A special thank to Dr. G. Bauce (Hendrix, Verona, I) for the production of the extruded diet.

\section{References}

Alsted, N.S., 1991. Studies on the reduction of discharges from fish farms by modification of the diet. In: Cowey, C.B., Cho, C.Y. (Eds.), Proceedings of the First International Symposium on Nutrition Strategies in Management of Aquaculture Waste. Guelph, Ontario, 5-8 June 1990, Univ. of Guelph, Ontario, Canada, pp. 77-89.

AOAC, 1995. In: Cunniff, P. (Ed.), Official Methods of Analysis of AOAC, Vol. I, 16th edn. AOAC International, Suite 400 Wilson Boulevard, Arlington, VA, 22201 USA.

Arnesen, P., Krogdahl, A., 1993. Crude and pre-extruded products of wheat as nutrient sources in extruded diets for Atlantic salmon (Salmo salar, L) grown in sea water. Aquaculture 118, 105-117.

Ballestrazzi, R., Lanari, D., 1996. Growth, body composition and nutrient retention efficiency of growing sea-bass (Dicentrarchus labrax, L.) fed fish oil or fatty acid Ca salts. Aquaculture 139, 101-108.

Ballestrazzi, R., Lanari, D., D’Agaro, E., Mion, A., 1994. The effect of dietary protein level and source on growth, body composition, total ammonia and reactive phosphate excretion of growing sea bass ( $\mathrm{Di}$ centrarchus labrax). Aquaculture 127, 197-206.

Brett, J.R., Groves, T.D.D., 1979. Physiological energetics. In: Hoar, W.S., Randall, D.J., Brett, J.R. (Eds.), Fish Physiology, Vol. VIII. Bioenergetics and Growth. Academic Press, New York, pp. 279-352.

Brett, J.R., Zala, C.A., 1975. Daily pattern of nitrogen excretion and oxygen consumption of sockeye salmon (Oncorhynchus nerka) under controlled conditions. J. Fish Res. Bd. Can. 32, 2479-2486.

Cho, C.Y., 1992. Feeding systems for rainbow trout and other salmonids with reference to current estimates of energy and protein requirement. Aquaculture 100, 107-123.

Cho, C.Y., 1993. Digestibility of feedstuffs as a major factor in aquaculture waste management. In: Kaushik, S.J., Luquet, P. (Eds.), Fish Nutrition in Practice. Les Colloques No. 61, INRA edn., Versailles Cedex, France, pp. 365-374.

Cho, C.Y., Hynes, J.D., Wood, K.R., Yoshida, H.K., 1991. Quantitation of fish culture wastes by biological (nutritional) and chemical (limnological) methods; the development of high nutrient dense (HND) diets. In: Cowey, C.B., Cho, C.Y. (Eds.), Proceedings of the First International Symposium on Nutrition Strategies in Management of Aquaculture Waste. Guelph, Ontario, 5-8 June 1990, Univ. of Guelph, Ontario, Canada, pp. 37-50.

Enell, M., 1987. Environmental impact of cage fish farming. Rep. Inst. Freshwater Res. 63, 106.

Guérin- Ancey, O., 1976. Etude experimentale de l'excretion azotèe du bar (Dicentrarchus labrax) en cours de croissance: II. Effets du jeûne sur l'excretion d'ammoniac et d'urée. Aquaculture 9, 187-194.

Hidalgo, F., Alliot, E., 1988. Influence of water temperature on protein requirement and protein utilization in juvenile sea bass, Dicentrarchus labrax. Aquaculture 72, 115-129.

Hilton, J.W., Cho, C.Y., Slinger, S.J., 1981. Effect of extrusion processing and steam pelleting diet on pellet durability, pellet water absorption, and the physiological response of rainbow trout (Salmo gairdneri R.). Aquaculture 25, 185-194.

Iwata, K., 1970. Relationship between food and growth in young crucia carps, Carassius auratus cuvieri, as determined by the nitrogen balance. Jpn. J. Limnol. 31, 129-151.

Johnsen, F., Wandsvik, A., 1991. The impact of high energy diets on pollution control in the farming industry. In: Cowey, C.B., Cho, C.Y. (Eds.), Proceedings of the First International Symposium on Nutrition Strategies in Management of Aquaculture Waste. Guelph, Ontario, 5-8 June 1990, Univ. of Guelph, Ontario, Canada, pp. 51-63.

Johnsen, F., Hillestad, M., Austreng, E., 1993. High energy diets for Atlantic salmon. Effects on pollution. In: Kaushik, S.J., Luquet, P. (Eds.), Fish Nutrition in Practice. Les Colloques No. 61, INRA edn., Versailles Cedex, France, pp. 391-402.

Kaushik, S.J., 1980. Influence of nutritional status on the daily patterns of nitrogen excretion in the carp (Cyprinus carpio L.) and the rainbow trout (Salmo gairdneri). Reprod. Nutr. Dev. 20, 1751-1765. 
Kaushik, S.J., Cowey, C.B., 1991. Dietary factors affecting nitrogen excretion by fish. In: Cowey, C.B., Cho, C.Y. (Eds.), Proceedings of the First International Symposium on Nutrition Strategies in Management of Aquaculture Waste. Guelph, Ontario, 5-8 June 1990, Univ. of Guelph, Ontario, Canada, pp. 3-19.

Kaushik, S.J., Medale, F., Fauconneau, B., Blanc, D., 1989. Effect of digestible carbohydrates on protein/energy utilization and on glucose metabolism in rainbow trout (Salmo gairdneri, R.). Aquaculture 79, 63-74.

Kiaerskou, J., 1991. Production and economics of 'low pollution diets' for the aquaculture industry. In: Cowey, C.B., Cho, C.Y. (Eds.), Proceedings of the First International Symposium on Nutrition Strategies in Management of Aquaculture Waste. Guelph, Ontario, 5-8 June 1990, Univ. of Guelph, Ontario, Canada, pp. 65-76.

Lall, S.P., 1991. Digestibility, metabolism and excretion of dietary phosphorus in fish. In: Cowey, C.B., Cho, C.Y. (Eds.), Proceedings of the First International Symposium on Nutrition Strategies in Management of Aquaculture Waste. Guelph, Ontario, 5-8 June 1990, Univ. of Guelph, Ontario, Canada, pp. 21-36.

Lanari, D., D'Agaro, E., Ballestrazzi, R., 1995. Dietary N and P levels, effluent water characteristics and performance in rainbow trout. Water Sci. Technol. 31 (10), 157-165.

Luquet, P., Bergot, F., 1976. Evaluation de divers traitements technologiques des céréales. Ann. Zootech. 25, 63-69.

Metailler, R., Dehapiot, T., Huelvan, C., Vandeville, J.E., 1980. Influence of the feeding level on growth, food conversion, protein efficiency and chemical composition of juvenile European sea bass, Dicentrarchus labrax. Proc. World Maricult. Soc. 11, 436-444.

Metailler, R., Aldrin, J.F., Messager, J.L., Mavel, G., Stephan, G., 1981. Feeding of juvenile European sea bass, Dicentrarchus labrax: role of protein level and energy source. J. World Maricult. Soc. 12, 117-118.

Mosconi-Bac, N., 1990. Reversibility of artificial feed-induced hepatociyte disturbances in cultured juvenile sea bass (Dicentrarchus labrax): an ultrastructural study. Aquaculture 88, 363-370.

Ogino, C., Kakino, J., Chen, M.S., 1973. Protein nutrition in fish: II. Determination of metabolic fecal nitrogen and endogenous nitrogen excretion of carp. Nippon Suisan Gakkaishi 39, 519-523.

Persson, G., 1988. Relationship between feed, productivity and pollution in the farming of large rainbow trout (Salmo gairdneri). Swedish Environmental Protection Agency, Stockolm, PM3534, 48 pp.

Pfeffer, E., Beckmann-Toussaint, J., Henrichfreise, B., Jansen, H.D., 1991. Effect of extrusion on efficiency of utilization of maize starch by rainbow trout (Oncorhynchus mykiss). Aquaculture 96, 293-303.

Pieper, A., Pfeffer, E., 1980. Studies on the comparative efficiency of utilization of gross energy from some carbohydrates, proteins and fats by rainbow trout (S. gairdneri R.). Aquaculture 20, 323-332.

Reinitz, G., 1983. Relative effect of age, diet and feeding rate on the body composition of young rainbow trout (Salmo gairdneri). Aquaculture 35, 19-27.

Robert, N., le Gouvello, R., Mauviot, J.C., Arroyo, F., Aguirre, P., Kaushik, S.J., 1993. Use of extruded diets in intensive trout culture: effects of protein to energy ratios on growth, nutrient utilization and on flesh and water quality. In: Kaushik, S.J., Luquet, P. (Eds.), Fish Nutrition in Practice. Les Colloques No. 61, INRA edn., Versailles Cedex, France, pp. 497-500.

Sanderson, P., 1986. A new method of analysis of feedstuffs for the determination of crude oils and fats. In: Wiseman, J. (Ed.), Recent Advances in Animal Nutrition. Butterworth, London, pp. 77-81.

Savitz, J., 1969. Effects of temperature and body weight on endogenous nitrogen excretion in the bluegill sunfish (Lepomis macrochirus). J. Fish. Res. Bd. Can. 26, 1813-1821.

Silver, G.R., Higgs, D.A., Dosanjh, B.S., McKeown, B.A., Deacon, G., French, D., 1993. Effect of dietary protein to lipid ratio on growth and chemical composition of chinook salmon (Oncorhynchus tshawytscha) in sea water. In: Kaushik, S.J., Luquet, P. (Eds.), Fish Nutrition in Practice. Les Colloques No. 61, INRA edn., Versailles Cedex, France, pp. 459-466.

Slinger, S.J., Razzaque, A., Cho, C.Y., 1979. Effect of feed processing and leaching on the losses of certain vitamins in fish diets. In: Halver, J.E., Tiews, K. (Eds.), Finfish Nutr. Fishfeed Technol., Vol. II. Heenemann, Berlin, pp. 425-434.

Snedecor, G.W., Cochran, W.G., 1982. Statistical Methods. The Iowa State Univ. Press, 507 pp.

Spiridakis, P., 1989. Utilisation des protéines alimentaires chez le bar (Dicentrarchus labrax). Aspects digestifs et métaboliques. Thése de Doctorat, université de Bretagne Occidentale, 190 pp.

Storebakken, T., Austreng, E., 1987. Ration level for salmonids: II. Growth, feed intake, protein digestibility, body composition, and feed conversion in rainbow trout weighing $0.5-1.0 \mathrm{~kg}$. Aquaculture $60,207-221$. 
Strickland, J.D.H., Parson, T.R., 1972. A Practical Handbook of Seawater Analysis, 2nd edn. Fisheries Research Board of Canada, Bulletin 167, Ottawa, Ontario, p. 310.

Takeuchi, T., Jeong, K.-S., Watanabe, T., 1990. Availability of extruded carbohydrate ingredients to rainbow trout Oncorhynchus mykiss and carp Cyprinus carpio. Nippon Suisan Gakkaishi 56, 1839-1845.

Vitale-Lelong, D., 1989. Bilan azoté du loup (Dicentrarchus labrax, L.) en cours de prégrossissement. Vie Marine H.S. 11, 111. 